\title{
English Language Learners' Perceptions of Motivational Changes
}

\author{
Hsuan-Yau Tony Lai ${ }^{1} \&$ Kuang-yun Ting ${ }^{2}$ \\ ${ }^{1}$ Department of Applied Foreign Languages, National Taipei College of Business, Taipei City, Taiwan \\ ${ }^{2}$ Department of Applied English, St. John's University, New Taipei City, Taiwan \\ Correspondence: Hsuan-Yau Tony Lai, Department of Applied Foreign Languages, National Taipei College of \\ Business, Taipei City, 100, Taiwan. Tel: 886-2-2322-6607. E-mail: tony823@ms17.hinet.net
}

Received: May 6, 2013 Accepted: May 21, 2013 Online Published: July 4, 2013

doi:10.5539/elt.v6n8p10 URL: http://dx.doi.org/10.5539/elt.v6n8p10

\begin{abstract}
This study explores the changes in Taiwanese university students' English-learning motivation and the causes of these changes. The emphasis herein is on a comparison and contrast of both English major and non-major students in three different universities in Taiwan. In the study, a qualitative approach $(20$ semi-structured interviews) was used. The results show that the majority (19 out of 20) of the university students in this study have experienced motivational changes in their English-learning process. The factors which changed both English major and non-major students' English-learning motivation share similarities in many ways. In other words, students' majors do not affect the changes in their motivation with respect to their English classroom experience. As pointed out by the university students in this study, influences such as teachers, external pressure, exams, group dynamics and social experiences, were responsible for the changes. This paper will consider possible implications of this insight for English language teaching professionals.
\end{abstract}

Keywords: motivation, dynamic, process, influence, change

\section{Introduction}

In the L2 motivation field, scholars have approached the concept of learning motivation from various perspectives. L2 motivation has been divided into two dimensions: choice motivation (reasons) and executive motivation (learning process). However, in the Taiwanese EFL (English as a Foreign Language) context, it appears that little research has been done to explore university students' changes in motivation for studying English. In this study, a qualitative (semi-structured interviews) approach was conducted to investigate this issue. Since the reasons and degree of students' motivation for studying English may differ due to their major differences in ability, the study also puts emphasis on its comparison and contrast of both English majors and non-English majors from different universities in Taiwan.

\section{Literature Review}

In this literature review, relevant theories and concepts about L2 motivation as a process will be discussed. As well as these, a number of factors which are likely to influence the motivation process will also be discussed.

\subsection{L2 Motivation as a Dynamic Process}

Dörnyei (2003a, 2005) points out that there are three phases of L2 motivation research, which are: 1) the social psychological period (1959-1990); 2) the cognitive-situated period (during the 1990s); 3) the process-orientated period (late 1990s-present). The emphasis has been put on motivational changes in the third phase. As Dörnyei (2005, p. 83) argues, “...there is a need to adopt a process-oriented approach paradigm that can account for the daily ups and downs of motivation to learn, that is, the ongoing changes of motivation over time." Furthermore, he points out that the individual's learning motivation may even change during a single L2 class. A number of scholars also have been working on the notion of motivation as a dynamic process (see, for example, Williams \& Burden, 1997; Ushioda, 1996, 1998, 2001; Dörnyei \& Ottó, 1998; Dörnyei, 2001a).

Williams and Burden's (1997, p. 121) three-stage model ('Reasons for doing something' $\rightarrow$ 'Deciding to do something' $\rightarrow$ 'Sustaining the effort, or persisting') of motivation from a social constructive perspective also depicts the dynamics of motivation. Williams and Burden (1997) also categorise the first two stages as 'initiating motivation' and the final stage as 'sustaining motivation' and argue that the three stages occur within the framework of sociocultural contexts. In other words, the sociocultural influences may affect each stage 
respectively. Moreover, they believe that the model is not a one-way process and that the three stages are interrelated.

Apart from Williams and Burden's motivation model, Ushioda (2001) also proposes a theoretical framework of motivation from a temporal perspective based on her research findings. In her research which aimed to investigate French language learners' perceptions of motivational thinking and motivational changes over time at Trinity College Dublin, Ireland, she identifies eight descriptive motivational dimensions for learning French: 1). Academic interest; 2). Language-related enjoyment/liking; 3). Desired levels of L2 competence; 4). Personal goals; 5). Positive learning history; 6). Personal satisfaction; 7). Feelings about French-speaking countries or people; 8). External pressures/incentives.

Furthermore, Ushioda (2001) classifies these eight dimensions as either 'causal' (deriving from learners' L2 learning process and L2-related experience) or 'teleological' (directed towards future short-term or long-term goals), and develops her theoretical framework of motivation (see Figure 1). Based on her findings, Ushioda (2001) claims that positive learning experience is likely to trigger intrinsic motivational factors; however, learners with less successful learning experience tend to emphasise their personal goals as primary motivation for learning an L2.

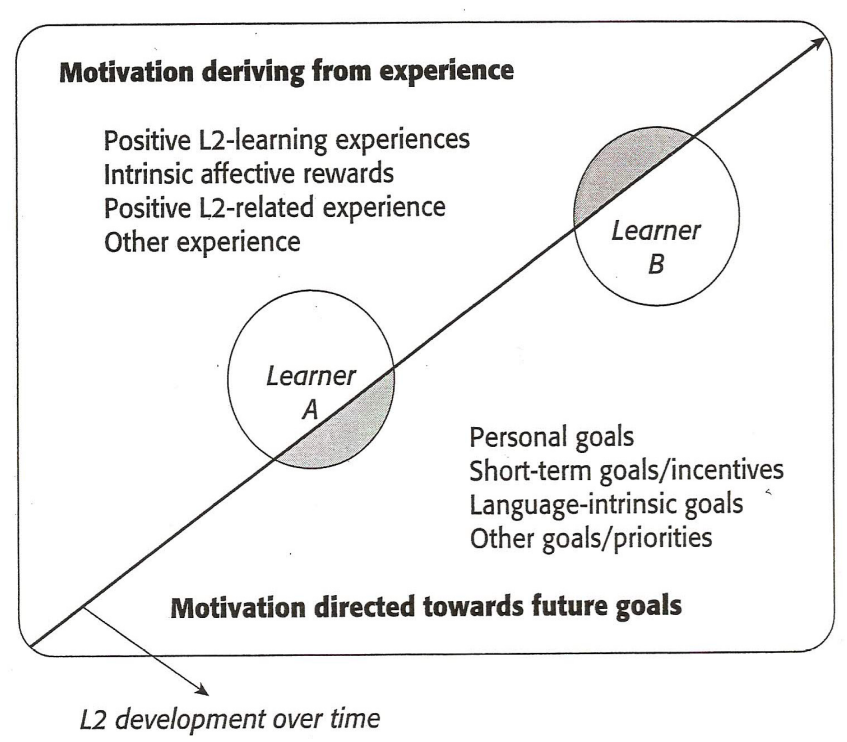

Figure 1. Ushioda's conceptualism of learner motivation

Another important process-orientated motivation model was developed by Dörnyei and Ottó (1998) and has undergone some modifications (see, for example, Dörnyei, 2000, 2001a). Dörnyei (2005, p. 84) believes that this model "describes how initial wishes and desires are first transformed into goals and then into operationalized intentions, and how these intentions are enacted, leading (hopefully) to the accomplishment of the goal and concluded by the final evaluation of the process." As Figure 2 shows, the three stages of L 2 motivation have been separated-Preactional Stage, Actional Stage and Postactional Stage. The preactional stage can be considered as an initial phase of generating motivation, i.e. 'choice motivation'. We can find that Williams and Burden's (1997) concept of 'initiating motivation' derived from their model is similar to this stage. Dörnyei (2005) also argues that Gardner's (1985) social psychology model mainly explores choice motivation and ignores the second stage - actional stage. At the actional stage, it is crucial to 'maintain' and 'protect' the generated motivation when doing an activity. This notion is referred to as 'executive motivation', which can be comparable with Williams and Burden's (1997) perspective of 'sustaining motivation'. However, in Dörnyei and Ottó's model, there is a third stage — postactional stage — which is referred to as 'motivational retrospection'. At this stage, the learners evaluate what they have done retrospectively and this process will normally have a certain impact on their motivation for doing other activities in the future. 


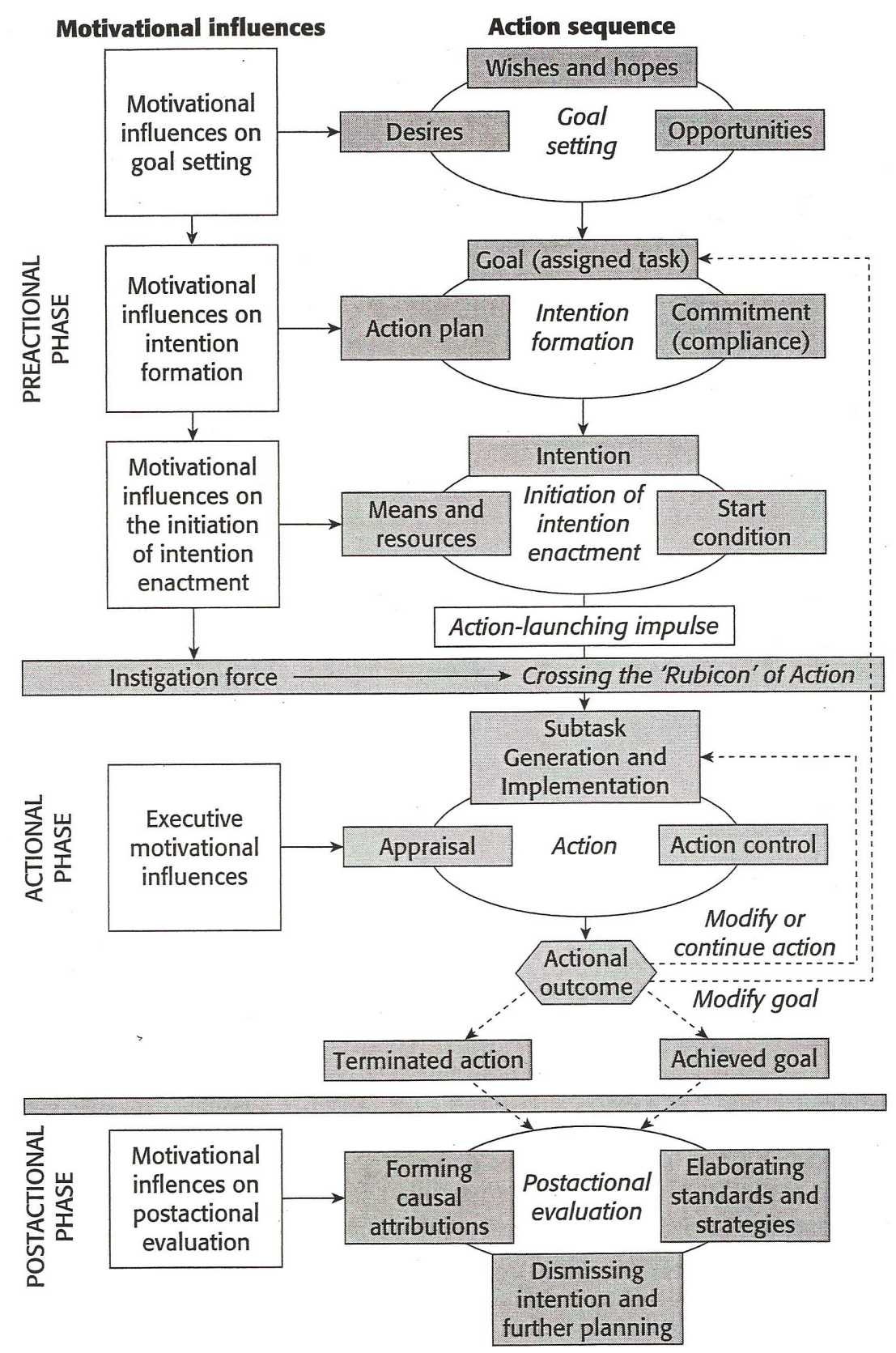

Figure 2. Dörnyei and Ottó's process model of L2 motivation

In this section, we have discussed L2 motivation from the perspective of process. The discussion above shows that L2 motivation is a dynamic concept and cannot be pinned down at one particular point. Next, we will discuss factors which are likely to influence L2 learners' motivational changes.

\subsection{Influences on Motivational Changes}

As we can see from the models discussed above, L2 motivation is not only about choices or orientations, but also a multidimensional and multidirectional process. Moreover, Dörnyei and Ottó's (1998) process model also addresses some main motivational influences at each stage respectively, which indicates that the individual's motivation is mediated and influenced by significant others and sociocultural factors. Before Dörnyei and Ottó (1998) proposed their process model, Williams and Burden (1997, p. 139-140) already identified some internal and external factors which might influence L2 learners' learning motivation as follows (Table 1). 
Table 1. Factors influence L2 learners' motivation

\begin{tabular}{|c|c|c|c|}
\hline $\begin{array}{l}\text { Significant } \\
\text { others }\end{array}$ & $\begin{array}{l}\text { The nature of interaction with } \\
\text { significant others }\end{array}$ & $\begin{array}{l}\text { The learning } \\
\text { environment }\end{array}$ & The broader context \\
\hline 1. parents & 1. mediated learning & 1. comfort & 1. wider family \\
\hline 2. teachers & experiences & 2. resources & networks \\
\hline \multirow[t]{5}{*}{ 3. peers } & $\begin{array}{l}\text { 2. the nature and amount of } \\
\text { feedback }\end{array}$ & $\begin{array}{l}\text { 3. time of day, week, } \\
\text { year }\end{array}$ & $\begin{array}{l}\text { 2. the local education } \\
\text { system }\end{array}$ \\
\hline & 3. rewards & 4. size of class and & 3. conflicting interests \\
\hline & 4. the nature and amount of & school & 4. cultural norms \\
\hline & appropriate praise & 5. class and school & 5. societal expectations \\
\hline & 5. punishment, sanctions & ethos & and attitudes \\
\hline
\end{tabular}

We can see that some factors from the above list coincide with Dörnyei and Ottó's (1998) motivational influences at the actional stage in their model, for instance, the learning experience factor. As discussed earlier, Ushioda $(1998,2001)$ also argues that L2 learners' past and current experience play a crucial role in affecting their motivational thinking. More recently, Dörnyei's $(2005,2009,2011)$ proposed an L2 Motivational Self System which consists of three components - Ideal L2 Self, Ought-to L2 Self and L2 Learning Experience-and it also demonstrates that executive motives are related to the immediate learning environment and experience (e.g. the impact of the teacher, the curriculum, the peer group, the experience of success). In addition to the experience factor, significant others such as teachers and parents have been extensively discussed as main motivational influences as well. Ryan and Deci (2000) believe that relatedness to significant others (e.g. teachers and parents) helps to facilitate internalisation of different regulations with respect to extrinsic motivation and to maintain a person's intrinsic motivation (see, Ryan, Stiller \& Lynch, 1994).

A number of scholars including Gardner (1985), Chambers (1999), Noels (2001), Dörnyei (2001b), Williams and Burden (1997) and Dörnyei and Csizér (1998) have suggested that motivational influences from language teachers are significant either in a positive or negative way. As Dörnyei (2001b, p. 35) points out, teachers are powerful motivational socialisers and "embody group conscience, symbolise the group's unity and identity, and serve as a model or a reference/standard."

Another major motivational influence from significant others is parental influences (Gardner, 1985; Noels, 2001; Dörnyei, 2001b, 2011; Eccles et al., 1998; Gardner et al., 1999). As Gardner (1985) argues, parents may affect their child's general beliefs about language learning and the L2 community and his/her attitudes towards some language courses actively or passively. Although parents are important to learners' motivation, Noels (2001) further broadens the scope to family members' influences. She points out that other family members such as spouses, grandparents or siblings may also affect L2 learners' motivation and argues that "familial influences on motivation are not restricted to parents, but, depending on the background and life experience of the learner, other members may also play important roles in supporting motivation" (Noels, 2001, p. 56). Interestingly, Noels (2001) points out that a person's romantic partner, i.e. a boyfriend or girlfriend who comes from another language community, may arouse his/her motivation for learning the language as well.

In addition to the factors of learning experience and significant others, group influences have been related to motivation and discussed widely as well. As Harter (1996, p. 11) points out, the classroom is a 'powerful social context'. Within this setting, learners' extrinsic and intrinsic motivation could be affected through interactions with teachers and classmates and learners may adjust their psychological thinking in response to the influences over time (see, for example, Wigfield et al., 1998). Wentzel (1999) also claims that a good relationship with peers may have a positive impact on students' motivation and may increase their interest in school work. On the other hand, if a student feels rejected by his/her peers, he/she might show a low level of interest in school work, and we can assume that his/her motivation will decrease. As Chang (2007) discovers, based on her research findings which aimed to explore group influences on Taiwanese undergraduates' English learning motivation, there is a correlation between group processes (group cohesiveness and group norms) and students' level of motivation (self-efficacy and level of autonomy). Her participants further commented that classmates played an important role in their learning process and that being near more motivated classmates might influence their motivation positively.

Apart from group influences, Noels (2001, p. 57) believes that members of the L2 community may facilitate L2 learners' motivation as well. She cites Clément $(1980,1986)$ and argues that the quality and frequency of contact with members of the L2 group will influence self-confidence, motivation, and ultimately language proficiency. Landry and Allard (1992; see, Allard \& Landry, 1992) further argue that the quantity of contact with the L2 members is an important predictor for language learning. However, as Labrie and Clément (1986) suggest, the 
quality of contact is far more important than the quantity is when shaping learners' motivation and self-confidence.

At different stages during the learning process, learners' motivation may change because of various motivational influences. The motivational influences we summarised here do not cover every aspect, since motivation is an abstract and multifaceted concept; however, they might give us some thoughts about how motivation can be influenced and by what and/or by whom.

Although the above related literature review sheds some light on L2 learners' changes in motivation and factors which are likely to influence their motivation, there is little empirical research focusing on investigating this issue in great detail, particularly in the Asian context. Our study fills in the gap and provides some implications for English language teaching professionals and educators in higher education.

\section{Methodology}

This section will introduce the research design of the study, including the participants, method, data collection, analysis and limitations.

In Taiwan, English is taught and learned as a foreign language. All Taiwanese students have to study English from elementary school through high school graduation. At the tertiary level, apart from English-major students, all non-English-major students in their first and/or second year are required to take English courses that focus on the four basic skills (reading, writing, speaking and listening). Some universities even offer English courses such as travelling English, news English, entertainment English, etc., as optional courses for students to take in years three and four.

\subsection{Participants and Method}

Since participants' major may affect changes in their motivation, this study takes a broad approach by exploring and comparing two groups of university students (English majors and non-English majors) regarding their perceptions of the changes in motivation in the process of studying English and the causes of those changes. In the past few decades, motivation research has been dominated by quantitative research such as survey studies, factor analytical studies, correlation studies or structural equation modelling. However, as Dörnyei (2001b, 2011) points out, motivation is an inconstant, multidimensional, abstract construct and is not directly observable. Ushioda (1994, p. 83) also argues that we may need new research approaches to explore the dynamic nature of L2 motivation. As she claims:

The generally positive impact of high levels of motivation on levels of L2 achievement has been extensively documented in the existing quantitative research tradition. A more introspective approach to the perceived dynamic interplay between learning experience and individual motivational thought processes may offer a better understanding of how these high levels of motivation might be effectively promoted and sustained.

Since motivational change is a complex and multifaceted issue, interviews are well suited to the purpose of this study. As Jones (1985) claims, depth interviews are often used to explore individuals' cognition which leads to their actual actions. Instead of having certain presumptions in mind when observing people's overt behaviour, it is important for researchers (and/or interviewers) to ask participants to speak in their own terms. In this study, a semi-structured interview was conducted because it was a compromise between structure and openness and was likely to cover a focused domain by using probes and prompts (Gillham, 2005). There were two interview questions:

1) 'While you are/were studying English in university, does/did your motivation change in any way? If so, what do you think are/were the major influences affecting you?'

2) 'Do you have any comments regarding your attitude to learning English?'

In total, twenty students from three different universities in central Taiwan were interviewed (see Table 2). Eight of them were male students.

Table 2. Distribution of the interview participants

\begin{tabular}{ll}
\hline & $\begin{array}{l}\text { Three different } \\
\text { universities in central Taiwan }\end{array}$ \\
\hline English-major students & $\begin{array}{l}n=9 \\
(5 \text { freshmen; } 3 \text { juniors; } \\
1 \text { senior })\end{array}$ \\
$\begin{array}{l}\text { non-English-major } \\
\text { students }\end{array}$ & $n=11$ (11 freshmen) \\
\hline
\end{tabular}




\subsection{Data Collection}

The data collection was carried out over a two-month period. Before beginning the study, we asked former colleagues and friends who taught English at different universities to explain the purpose of the study to their students and invited volunteers to participate. Twenty students were willing to help. All 20 interviews were conducted in Mandarin Chinese since the participants preferred this. Each interview, which took place in a quiet classroom at the three universities, lasted 20 to 40 minutes, and was audio recorded with the permission of each participant.

\subsection{Analysis}

The audio-recorded interview data were transcribed into Mandarin Chinese and then the content was analysed in English. First, we examined the data and listed all the influences that were mentioned by each participant to determine common themes. For example, a number of participants mentioned that their English-learning motivation changed because of pressure from schoolwork or after-school work (part-time jobs). We labelled these influences as 'external pressure'. The participants also indicated that their English-learning motivation changed either in a positive (increase) or negative (decrease) manner, or in both positive and negative manners. Because of this, a criterion (positive; negative; both) was added to determine how the participants saw these influences changing their motivation. Since the interview data were transcribed into Mandarin Chinese and then analysed for content, in order to avoid any translation bias, we asked two Taiwanese colleagues with a PhD degree in ELT (English Language Teaching) and Applied Linguistics to check the raw data in Mandarin Chinese and analyse the content in English.

\subsection{Limitations}

The study has a number of limitations. First, the 20 participants involved may not be able to represent the majority of Taiwanese university students' thinking. This is a disadvantage of qualitative research. However, the results do provide some insights into the students' perceptions of motivational changes. Second, before the interviews were conducted, we had not met or known most of these participants. As a result, a few participants were shy and reserved at the beginning of the interview and did not talk much about their experiences. However, when they got used to the interview and found something they would like to share, they tended to be more comfortable. Third, a couple of the participants tended to answer the questions with short answers. Although they did talk about their motivational changes, their short answers might not reveal their real thoughts and made the interview short, lasting about 15 to 20 minutes.

\section{Findings and Discussion}

The interview data suggested that 19 out of the 20 participants agreed that their motivation changed in different ways due to various influences. Only one non-English-major student stated that his English-learning motivation did not change at all. Table 3 lists the influences and shows how these influences affected participants' motivation.

Table 3. Participants' perceptions of motivational changes

\begin{tabular}{|c|c|c|c|c|c|c|c|}
\hline \multirow{2}{*}{ Influences } & \multicolumn{3}{|c|}{ English majors $(n=9)$} & \multirow{2}{*}{ Influences } & \multicolumn{3}{|c|}{ Non-English majors $(n=11)$} \\
\hline & Positive & Negative & Both & & Positive & Negative & Both \\
\hline Teachers & 2 & 2 & 2 & Teachers & 3 & 1 & 3 \\
\hline $\begin{array}{l}\text { External pressure } \\
\text { (schoolwork or } \\
\text { after-school work) }\end{array}$ & $\mathrm{N} / \mathrm{A}$ & 4 & N/A & $\begin{array}{l}\text { External pressure } \\
\text { (schoolwork) }\end{array}$ & N/A & 3 & N/A \\
\hline Curriculum & $\mathrm{N} / \mathrm{A}$ & 3 & N/A & Curriculum & 1 & 1 & N/A \\
\hline Family members & N/A & 2 & N/A & $\begin{array}{l}\text { Boyfriend/ } \\
\text { Girlfriend }\end{array}$ & 1 & N/A & N/A \\
\hline Peers & 1 & N/A & N/A & Peers & 1 & N/A & $\mathrm{N} / \mathrm{A}$ \\
\hline Exams & 1 & $\mathrm{~N} / \mathrm{A}$ & N/A & Exams & $\mathrm{N} / \mathrm{A}$ & 2 & $\mathrm{~N} / \mathrm{A}$ \\
\hline $\begin{array}{l}\text { Classroom } \\
\text { dynamics }\end{array}$ & $\mathrm{N} / \mathrm{A}$ & 1 & N/A & $\begin{array}{l}\text { Classroom } \\
\text { dynamics }\end{array}$ & N/A & N/A & 1 \\
\hline Short stays aboard & 1 & N/A & N/A & $\begin{array}{l}\text { Learning } \\
\text { environment }\end{array}$ & 1 & N/A & $\mathrm{N} / \mathrm{A}$ \\
\hline
\end{tabular}

The table indicates that teachers, external pressure (schoolwork or after-school work), curriculum, peers, exams 
and classroom dynamics were common influences mentioned by students (both English majors and non-English majors) at university. These findings support the discussion in the literature review indicating that motivation is a dynamic and constantly changing process that various factors influence; it cannot be considered a stable construct. The results further remind us of Ryan and Deci's (2000) notion that, with respect to the human motivation continuum, motivation develops through different stages and 'moves back and forth' between the most (e.g. intrinsic motivation or integrated regulation) and the least (e.g. external regulation or introjected regulation) self-determined ends. As the data suggest, various influences determine the changes in the students' motivation. Here, we will discuss a number of significant factors that most of the participants in the study identified.

\subsection{Significant Others}

The findings suggest that learners' significant others (teachers, peers, family members, boyfriend/girlfriend) are likely to influence their learning motivation. Among these significant others, teachers play a very (perhaps the most) crucial role in changing learners' motivation. In this study, 13 participants (EM: 6; NEM: 7) (EM=English Majors; NEM=Non-English Majors) pointed out that their learning motivation changed because of their English teachers. As one participant [EM] said, "Teachers' encouragement affects me a lot. I am a student who needs encouragement. If I am encouraged, I will do my best." Dörnyei (1994, 2001b, 2005, 2011), and Williams and Burden (1997) also claim that language teachers are significant others who are most likely to influence students' motivation in various ways.

However, teachers can also have a negative impact on students' motivation. Eight students (EM: 4; NEM: 4) commented that their teacher's teaching methods and competence demotivated them. They did not really like teachers who only read the textbook without providing any explanation, making the classroom atmosphere dull, or teachers who are incompetent or not suited to teaching the course. As one student [NEM] said: "Some teachers speak and teach really fast so that I cannot catch up. In the end, I'd rather stop listening to them and focus on my own stuff." Another participant [EM] complained, "I am disappointed that many teachers in my department don’t meet students' needs."

Although "teachers are powerful motivational socialisers" (Dörnyei, 2001b, p. 35), they serve as some students' 'demotivating' factor as well. Previously, a number of scholars worked on researching demotivating factors that might influence students in the classroom (see, for example, Gorham \& Christophel, 1992; Christophel \& Gorham, 1995; Oxford, 1998; Dörnyei, 1998; Sakai \& Kikuchi, 2009). Results suggest that teachers are one of the major demotivating factors identified by students. Based on his qualitative findings of investigating demotivation in second language learning, Dörnyei (1998) categorised nine types of negative influences. Among them, the role of teachers, including teachers' personality, commitment, competence, and teaching method, tops his list. Similar to this finding, eight students in our study also pointed out that their teachers demotivated them in different ways, some of these ways being especially the teacher's level of commitment, competence, and teaching methods.

\subsection{Curriculum}

In this study, five participants (EM: 3; NEM: 2) agreed that the curriculum affected their motivation for studying English. Among them, three (EM) complained about the curriculum and indicated there was a gap between their expectations and the curriculum. One student (EM) even complained that the gap between her expectations and the curriculum demotivated her right from her enrolment in the programme. On the other hand, one student (NEM) commented how he benefited from the curriculum because it equipped him with knowledge and helped him prepare for the General English Proficiency Test (GEPT). A number of scholars have discussed the influence of the curriculum (or course-specific aspects) on students' motivation (see, for example, Dörnyei, 1994; Williams \& Burden, 1997). In the preceding discussions, the influences of teachers and curriculum are likely to change learners' motivation for studying English in both positive and negative ways.

\subsection{Exams}

Before we began our data collection, we assumed that exams might play a crucial and negative role in Taiwanese students' motivational changes. Since we are Taiwanese and have had 17 years of education in Taiwan, we know the education system (and the traditional cultural value as well) is very exam-orientated. However, although a couple of the students (NEM: 2) mentioned they did not like taking exams, most students interviewed neither identified this as a factor nor agreed that exams demotivated them. On the contrary, they believed that exams (or tests) facilitated their English study and they were already used to the system. As one participant (NEM) said:

If we have tests regularly, maybe we can make progress faster because we can learn things systematically. However, if we only have the mid-term and final exams in one semester, we probably will not be able to absorb the content or knowledge, even though everyone attends the lectures and does the homework. 
Chen, Warden, and Chang explored Taiwan's unique 'exam culture' (2005) in their research, investigating 567 Taiwanese EFL learners' motivation orientation, expectancy, and self-evaluated skill. Their research findings identified a new motivation orientation, 'required orientation', which strongly correlates with Taiwanese English learners' past and future expectations and has existed in Chinese culture for a long time. Required orientation refers to passing various exams such as entrance exams, required classes, elective classes, and employment exams. In Chinese culture, this required orientation plays a crucial role since passing exams is the only way to enter a good school/university, have a good job, and a good life. The prerequisite for realising these fruitful dreams (images) is to bear the pressure and pass the exams successfully. The notion of required orientation seems to reflect the thought of Williams and Burden (1997) that the broader context (wider family networks, the local educational system, conflicting interests, cultural norms, and societal expectations and attitudes) has a profound external impact on L2 learners' motivation. Exams might not always be a demotivating factor; instead, they could be a positive force in changing students' motivation for learning English in Taiwan.

\subsection{Other Influences}

Apart from the three influences identified by the students, other factors, such as group dynamics, social experiences (meeting foreigners, travelling/short stays abroad and/or having a foreign boyfriend/girlfriend), and the learning environment also cause students' motivation to change. First, group dynamics in the English classroom seems to be another influential factor. One student (NEM) pointed out that the classroom atmosphere, and the interaction among students and/or with teachers changed her motivation both positively and negatively. Another participant (EM) stated that:

I think group work is a torture to me because some of the members are irresponsible and finish their work without making any effort. Normally, I am the one to put everyone's work together. Actually, however, it is always me helping everyone finish his or her work, and check everything. I am so fed up.

These findings repeat the discussion in the literature review that the learner group does influence students' executive motivation.

Second, in addition to group dynamics, two participants (EM: 1; NEM: 1) indicated that meeting foreigners on campus or in Taiwan, travelling abroad, studying abroad, and having a foreign boyfriend/girlfriend all had a positive impact on pushing them to study English. These findings suggest that social experiences (or encounters) are likely to change learners' motivation for studying English in a positive manner, although presumably, they could also have negative effects on motivation depending on the quality of the social experience. Ryan and Deci (2000) also point out that social contexts play an important role in facilitating internalisation and integration of extrinsic motivation and sustaining intrinsic motivation. They believed that significant others such as a family, a peer group, or society, support the internalisation and integration process for self-determination. The current study's finding that social experiences (or encounters) changed some students' motivation for studying English has demonstrated that social contexts impact individuals' motivation.

Third, one participant (NEM) commented that the learning environment in Taiwan offered little opportunity to use English in daily life, which sometimes hindered students' motivation for studying. As one interviewee said, "I think the surrounding environment affects my motivation because most of my classmates, friends, and relatives don't speak English." Williams and Burden (1997) claim that the learning environment is an important external factor determining learners' motivation. Similar to their claim, the third component of Dörnyei's (2005) L2 Motivation Self System: L2 Learning Experience, also indicates that executive motives relate to the immediate learning environment and experience.

Finally, four students (EM: 2; NEM: 2) who answered the last open-ended question (Do you have any comments regarding your attitude to learning English?) commented, "If Chinese (Taiwan's official language) is increasingly popular and important in the world today, do people in Taiwan need to 'chase the English language blindly?"' The data suggest these students have begun to question whether Chinese may become one of the most important international languages in the near future, and, if so, why they should study English. In recent years, many Chinese language centres established in Taiwan have attempted to meet a great demand from foreigners to learn Chinese. Teaching Chinese seems to be rising in popularity and gaining the spotlight in Taiwan. This tendency may have influenced some university students to begin questioning the role of English and may have given them an excuse for refusing to study English. However, given its growing status in the world and the vast number of L1 (first language) Chinese speakers, the case of Chinese here is unique. Therefore, this L1 influence on L2 demotivation is specific to the case of L1 Chinese speakers and might not be applicable to L1 users of other languages. This unique finding invites further investigation. 


\section{Conclusion and Suggestions}

As discussed, motivation is a complex and multifaceted concept and cannot be considered only as a cause or an outcome since it is a socially mediated process. The individual's motivation not only comes from within, but also develops through interacting with others in the surrounding sociocultural context. As the findings suggest, most participants experienced changes in their motivation for studying English. Several factors, including teachers, curriculum, exams, group dynamics, social experiences, and the learning environment, changed their motivation both positively and negatively. These influences could be from significant others and the learning environment and/or from the broader context of the education system or cultural and societal norms.

Although the findings of this study might not represent the majority of Taiwanese university students' perceptions since we adopted convenience sampling, they do shed some light on the issue of motivational changes and the factors that cause those changes. However, what do these findings imply? Since most participants in the study considered teachers to be the most important influence on their motivation, how can English (or other foreign language) teachers deal with learners' motivational changes?

It is essential that language teachers and curriculum designers ask themselves what their students need and want in the classroom. Since the findings show that L2 motivation is a dynamic process, teachers ought to be dynamic and flexible. Adopting a learner-centred approach and giving students a sense of autonomy for their own learning are crucial to increasing intrinsic motivation to study a second/foreign language.

\section{References}

Allard, R., \& Landry, R. (1992). Ethnolinguistic vitality beliefs and language maintenance and loss. In W. Fase, K. Jaspaertm, \& S. Kroon (Eds.), Maintenance and loss of minority languages (pp. 171-195). Amsterdam: John Benjamins.

Chambers, Gary N. (1999). Motivation language learners. Clevedon: Multilingual Matters. http://dx.doi.org/10.1080/09571739985200021

Chang, L. Y.-H. (2007). The influences of group processes on learners' autonomous beliefs and behaviors. System, 35(3), 322-337. http://dx.doi.org/10.1016/j.system.2007.03.001

Chen, J. F., Warden, C. A., \& Chang, H.-T. (2005). Motivation That Do Not Motivate: The Case of Chinese EFL Learners and the Influence of Culture on Motivation. TESOL Quarterly, 39(4), 609-633. http://dx.doi.org/10.2307/3588524

Christophel, D. M., \& Gorham, J. (1995). A test-retest analysis of student motivation, teacher immediacy and perceived sources of motivation and demotivation in college classes. Communication Education, 44, 292-306. http://dx.doi.org/10.1080/03634529509379020

Clément, R. (1980). Ethnicity, contact and communicative competence in a second language. In H. Giles, W. P. Robinson, \& P. M. Smith (Eds.), Language: Social psychological perspectives (pp. 147-154). Oxford: Pergamon.

Clément, R. (1986). Second language proficiency and acculturation: An investigation of the effects of language status and individual characteristics. Journal of Language and Social Psychology, 5, 290. http://dx.doi.org/10.1177/0261927X8600500403

Dörnyei, Z. (1994). Motivation and Motivating in the Foreign Language Classroom. Modern Language Journal, 78, 273-284. http://dx.doi.org/10.2307/330107

Dörnyei, Z. (1998). Demotivation in foreign language learning. Paper presented at the TESOL ' 98 Congress, March 17-21, in Seattle, USA.

Dörnyei, Z. (2000). Motivation in action: Towards a process-oriented conceptualisation of student motivation. British Journal of Educational Psychology, 70, 519-538. http://dx.doi.org/10.1348/000709900158281

Dörnyei, Z. (2001a). Motivational Strategies in the Language Classroom. Cambridge: Cambridge University Press. http://dx.doi.org/10.1017/CBO9780511667343

Dörnyei, Z. (2001b). Teaching and researching motivation. Essex: Pearson Education.

Dörnyei, Z. (2003a). Attitudes, orientations, and motivations in language learning: Advances in theory, research, and applications. In Z. Dörnyei (Ed.), Attitudes, orientations and motivations in language learning (pp. 3-32). Oxford: Blackwell.

Dörnyei, Z. (2003b). Questionnaire in second language research: Construction, administration, and processing. 
Mahwah: Lawrence Erlbaum Associates.

Dörnyei, Z. (2005). The Psychology of the Language Learner: Individual Differences in Second Language Acquisition. London: Lawrence Erlbaum Associates. http://dx.doi.org/10.1017/S0272263105370288

Dörnyei, Z. (2009). The L2 Motivational Self System. In Z. Dörnyei, \& E. Ushioda (Eds.), Motivation, Language Identity and the L2 Self (pp. 9-42). Bristol: Multilingual Matters.

Dörnyei, Z., \& Csizér, K. (1998). Ten commandments for motivating language learners: Results of an empirical study. Language Teaching Research, 2, 203-229. http://dx.doi.org/10.1177/136216889800200303

Dörnyei, Z., \& Ottó, I. (1998). Motivation in Action: A Process Model of L2 Motivation. Working Papers in Applied Linguistics, 4, 43-69.

Dörnyei, Z., \& Ushioda, E. (2011). Teaching and researching motivation (2nd Ed.). Harlow: Pearson Education Limited.

Eccles, J. S., Wigfield, A., \& Schiefele, A. (1998). Motivation to succeed. In W. Damon, \& N. Eisenberg (Eds.), Handbook of child psychology (5 $5^{\text {th }}$ ed.), Vol. 3: Social, emotional, and personality development (pp. 1017-1095). New York: John Wiley \& Sons.

Gardner, R. C. (1985). Social Psychology and Second Language Learning: The Role of Attitudes and Motivation. London: Edward Arnold.

Gardner, R. C., Masgoret, A. M., \& Tremblay, P. F. (1999). Home background characteristics of second language learning. Journal of Language and Social Psychology, 18, 419-437. http://dx.doi.org/10.1177/0261927X99018004004

Gillham, B. (2005). Research Interviewing: The range of techniques. Maidenhead: Open University Press.

Gorham, J., \& Christophel, D. M. (1992). Students' perceptions of teacher behaviors as motivating and demotivating factors in college classes. Communication Quarterly, 40, 239-252. http://dx.doi.org/10.1080/01463379209369839

Harter, S. (1996). Teacher and classmate influences on scholastic motivation, self-esteem, and level of voice in adolescents. In J. Juvonen, \& K. R. Wentzel (Eds.), Social Motivation: Understanding Children's School Adjustment (pp. 11-42). Cambridge: Cambridge University Press. http://dx.doi.org/10.1017/CBO9780511571190.004

Jones, J. (1985). Depth interviewing. In R. Walker (Ed.), Applied Qualitative Research (pp. 45-55). Brookfield: Gower.

Labrie, N., \& Clément, R. (1986). Ethnolinguistic vitality, self-confidence and second language proficiency: An investigation. Journal of Multilingual and Multicultural Development, 7, 269-282. http://dx.doi.org/10.1080/01434632.1986.9994244

Landry, R., \& Allard, R. (1992). Ethnolinguistic vitality and the bilingual development of minority and majority group students. In W. Fase, K. Jaspaert, \& S. Kroon (Eds.), Maintenance and loss of minority languages (pp. 223-251). Amsterdam: John Benjamins.

Noels, K. A. (2001). New Orientations in Language Learning Motivation: Towards a Model of Intrinsic, Extrinsic, and Integrative Orientations and Motivation. In Z. Dörnyei, \& R. Schmidt (Eds.), Motivation and Second Language Acquisition (pp. 43-68). Honolulu: University of Hawaii Press.

Oxford, R. L. (1998). The unravelling tapestry: Teacher and course characteristics associated with demotivation in the language classroom. Demotivation in foreign language learning. Paper presented at the TESOL '98 Congress, March 17-21, in Seattle, USA.

Ryan, R. M., \& Deci, E. L. (2000). Intrinsic and Extrinsic Motivations: Classic Definition and New Directions. Contemporary Educational Psychology, 25, 54-67. http://dx.doi.org/10.1006/ceps.1999.1020

Ryan, R. M., Stiller, J., \& Lynch, J. H. (1994). Representations of relationships to teachers, parents, and friends as predictors of academic motivation and self-esteem. Journal of Early Adolescence, 14, $226-249$. http://dx.doi.org/10.1177/027243169401400207

Sakai, H., \& Kikuchi, K. (2009). An analysis of demotivators in the EFL classroom. System, 37(1), 57-69. http://dx.doi.org/10.1016/j.system.2008.09.005

Ushioda, E. (1994). L2 motivation as a qualitative construct. Teanga, 14, 76-84. 
Ushioda, E. (1996). Developing a dynamic concept of motivation. In T. J. Hickey (Ed.), Language, education and society in a changing world (pp. 239-245). Clevedon: Multilingual Matters.

Ushioda, E. (1998). Effective motivational thinking: A cognitive theoretical approach to the study of language learning motivation. In E. A. Soler, \& V. C. Espurz (Eds.), Current issues in English language methodology (pp. 77-89). Castelló de la Plana: Universitat Jaume I.

Ushioda, E. (2001). Language learning at university: Exploring the role of motivational thinking. In Z. Dörnyei, \& R. Schmidt (Eds.), Motivation and second language acquisition (pp. 91-124). Honolulu: University of Hawaii Press.

Wentzel, K. R. (1999). Social-motivational processes and interpersonal relationships: Implications for understanding motivation at school. Journal of Educational Psychology, 91, 76-97. http://dx.doi.org/10.1037/0022-0663.91.1.76

Wigfield, A., Eccles, J. S., \& Rodriguez, D. (1998). The development of children's motivation in school contexts. Review of Research in Education, 23, 73-118. http://dx.doi.org/10.2307/1167288

Williams, M., \& Burden, R. L. (1997). Psychology for Language Teachers. Cambridge: Cambridge University Press. http://dx.doi.org/10.1177/0261927X970163001

\section{Copyrights}

Copyright for this article is retained by the author(s), with first publication rights granted to the journal.

This is an open-access article distributed under the terms and conditions of the Creative Commons Attribution license (http://creativecommons.org/licenses/by/3.0/). 